\title{
KLASIFIKASI DAYA TARIK WISATA UNGGULAN PROVINSI BENGKULU SEBAGAI UPAYA MENYONGSONG VISIT 2020 WONDERFUL BENGKULU
}

\author{
Dwi Oktavallyan Saputri \\ Program Studi Arsitektur Fakultas Teknik Universitas Bengkulu \\ Email: dwioktavally@gmail.com \\ Zamdial Ta'alidin \\ Program Studi Kelautan Fakultas Pertanian Universitas Bengkulu \\ Email: zamdial_et@yahoo.co.id \\ Atik Prihatiningrum \\ Program Studi S1 Arsitektur Fakultas Teknik Universitas Bengkulu \\ Email: atikprihatiningrum@gmail.com
}

\begin{abstract}
Bengkulu Province has begun to aware to its tourism potential, hence a program called "Visit 2020 Wonderful Bengkulu" was conducted and held by all Regencies / Cities of Bengkulu Province. Bengkulu Province has tremendous tourism potential to be developed, thus it is necessary to classify leading tourist attractions in an effort to support the program. The research method used is descriptive qualitative and quantitative, namely describing observations through field observations and direct assessments using the Tourism Attraction Assessment Guidelines in a systematic and actual procedure. The results is Bengkulu Province has few potential tourism, however, in general the potential is still not balanced by the availability of adequate accessibility and facilities / amenities. Almost all tourist attractions in 10 regencies / cities in Bengkulu Province in general are still insufficient in the management, planning and developing tourism. This research is expected to become a guideline in the tourism development of Bengkulu Province in preparing to welcome the "Visit 2020 Wonderful Bengkulu" program.
\end{abstract}

Keywords: Potential, Tourist Attraction, Bengkulu 


\section{Pendahuluan}

Pariwisata dewasa ini merupakan suatu kebutuhan primer bagi manusia modern. Industri pariwisata pun ikut berkembang untuk mensejajarkan kebutuhan berwisata. Tidak hanya itu, sebagaimana yang diungkapkan oleh Menteri Pariwisata, Arief Yahya, bahwa sumbangan devisa dari sektor pariwisata sejak tahun 2016 sudah mengalahkan pemasukan dari migas dan diperkirakan pada tahun 2019 sektor pariwisata menjadi penyumbang utama devisa Indonesia (DetikFinance, 2017).

Dalam menyambut euforia kepariwisataan ini Provinsi Bengkulu mencanangkan program "Visit 2020 Wonderful Bengkulu". Sudah menjadi rahasia umum bahwa Provinsi Bengkulu, sangat banyak memiliki sumberdaya pariwisata yang cukup potensial baik wisata alam, budaya maupun sejarah untuk dikembangkan dalam menarik minat wisatawan. Oleh karena itu, kemauan untuk terus mengembangkan dan memperkaya inovasi pariwisata harus senantiasa digelorakan dalam rangka menarik minat wisatawan nusantara maupun mancanegara.

Menurut Undang-Undang Republik Indonesia No. 10 Tahun 2009 tentang Kepariwisataan (pasal 1) disebutkan bahwa: “Daya Tarik Wisata adalah segala sesuatu yang memiliki keunikan, keindahan, dan nilai yang berupa keanekaragaman kekayaan alam, budaya, dan hasil buatan manusia yang menjadi sasaran atau tujuan kunjungan wisatawan." Untuk mendukung daya tarik wisata diperlukan suatu komponen produk pariwisata. Produk wisata merupakan keseluruhan pelayanan yang diperoleh dan dirasakan atau dinikmati wisatawan semenjak ia meninggalkan tempat tinggalnya, sampai ke daerah tujuan wisata yang telah dipilihnya dan kembali ke rumah dimana ia berangkat semula (Suwantoro, 1997:49). Produk wisata harus dipenuhi dalam memfasilitasi wisatawan dalam berwisata disuatu daya tarik wisata. 
Dari sekian banyak potensi dan daya tarik yang dimiliki Provinsi Bengkulu, maka perlu dilakukannya penelitian yang mengklasifikasikan daya tarik wisata unggulan Provinsi Bengkulu sebagai upaya menyongsong Visit 2020 Wonderful Bengkulu.

\section{Tinjauan Pustaka}

\section{Daya Tarik Wisata}

Menurut Pendit (1999) menerangkan bahwa potensi wisata adalah berbagai sumber daya yang terdapat di sebuah daerah tertentu yang bisa dikembangkan menjadi atraksi wisata. Dengan kata lain, potensi wisata adalah berbagai sumber daya yang dimiliki oleh suatu tempat/daerah yang dapat dikembangkan menjadi suatu atraksi wisata (tourist attraction) dan dimanfaatkan untuk kepentingan ekonomi dengan tetap memperhatikan aspek-aspek lainnya.

Menurut Witt (1994 dalam Basiya dan Rozak 2012) bahwa daya tarik tempat tujuan wisata merupakan motivasi utama bagi wisatawan untuk melakukan kunjungan wisata. Menurutnya destinasi wisata dikelompokkan menjadi empat daya tarik, yaitu :

1. Daya tarik wisata alam (natural attraction) yang meliputi pemandangan alam daratan, pemandangan alam lautan, pantai, iklim atau cuaca.

2. Daya tarik wisata berupa arsitektur bangunan (building attraction) yang meliputi bangunan dan arsitektur bersejarah, bangunan dan arsitektur modern, arkeologi.

3. Daya tarik wisata yang dikelola khusus (managed visitor attractions), yang meliputi tempat peninggalan kawasan industi seperti yang ada di Inggris, Theme Park di Amerika, Darling Harbour di Australia. 
4. Daya tarik wisata budaya (cultural attraction) yang meliputi teater, museum, tempat bersejara, adat-istiadat, tempat-tempat religius, peristiwaperistiwa khusus seperti festival dan drama bersejarah (pageants), dan heritage seperti warisan peninggalan budaya.

5. Daya tarik wisata sosial seperti gaya hidup penduduk di tempat tujuan wisata.

\section{Produk Pariwisata}

Produk pariwisata adalah sesuatu yang dapat ditawarkan kepada wisatawan untuk mengunjungi daya tarik wisata. Produk pariwisata merupakan faktor utama dalam memilih tujuan bagi wisatawan. Maka dari itu, produk wisata memiliki peran yang sangat penting dan harus dipelihara, serta dilakukan pemasaran/promosi dengan benar. Berdasarklan karakteristik daya tarik wisata, maka penyedia produk pariwisata dapat mewujudkan produk pariwisata yang sesuai dan diharapkan oleh wisatawan selama melakukan perjalanan wisatanya.

Menurut Suswantoro (2007) pada hakekatnya pengertian produk wisata adalah keseluruhan pelayanan yang diperoleh dan dirasakan atau dinikmati wisatawan semenjak ia meninggalkan tempat tinggalnya sampai ke daerah tujuan wisata yang dipilihnya dan sampai kembali kerumah dimana ia berangkat semula. Sehingga dapat disimpulkan bahwa produk pariwisata adalah keseluruhan pelayanan yang diberikan kepada wisatawan selama melakukan perjalanan wisata. Produk pariwisata tidak hanya diberikan saat wisatawan berada di destinasi wisata, melainkan juga sebelum keberangkatan dan setelah melakukan perjalanan.

Produk wisata menurut Yoeti (2008) sebagai salah satu obyek penawaran dalam pemasaran pariwisata memiliki unsur-unsur utama yang terdiri 3 bagian, sebagai berikut: 
a. Atraksi atau daya tarik daerah tujuan wisata, semua objek dan atraksi yang tersedia sebagai daya tarik mengapa wisatawan mau datang berkunjung ke negara, kota atau DTW tersebut.

b. Amenities atau fasilitas yaitu semua bentuk fasilitas yang memberikan pelayanan bagi wisatawan untuk segala kebutuhan selama tinggal atau berkunjung pada suatu DTW, seperti: hotel, motel, restoran, bar, cafe, shoping center, sovenir shop.

c. Aksesibilitas atau kemudahan untuk mencapai daerah tujuan wisata tersebut.

Menurut Medlik dan Middleton (1973 dalam Yoeti 2008), produk pariwisata terdiri dari bermacam-macam unsur yang merupakan suatu paket yang satu sama lainnya tidak terpisahkan serta memenuhi kebutuhan wisatawan sejak meninggalkan tempat tinggalnya sampai ketempat tujuannya dan kembali lagi ketempat asalnya. Menurut Burkat dan Medlik (1986 dalam Yoeti 2008), yang dimaksudkan dengan produk industri pariwisata adalah suatu susunan produk yang terdiri dari campuran: atraksi wisata, transportasi, akomodasi, dan hiburan;

Menurut Yoeti (2008), terdapat tiga elemen produk pariwisata. Elemen ini antara lain adalah:

1) Atraksi atau daya tarik daerah tujuan wisata, semua objek dan atraksi yang tersedia sebagai daya tarik mengapa wisatawan ingin datang berkunjung ke negara, kota atau DTW tersebut.

2) Amenities atau fasilitas yaitu semua bentuk fasilitas yang memberikan pelayanan bagi wisatawan untuk segala kebutuhan selama tinggal atau berkunjung pada suatu DTW, seperti: hotel, motel, restoran, bar, cafe, shoping center, souvenir shop.

3) Aksesibilitas atau kemudahan untuk mencapai daerah tujuan wisata tersebut. 
Yoeti (1997) juga mengatakan bahwa bagaimana objek wisata dimana atraksi dan fasilitas yang akan dijual, apakah memenuhi tiga syarat, yaitu:

1) Apa yang dilihat (something to see)

2) Apa yang dilakukan (something to do)

3) Apa yang dapat dibeli (something to buy)

\section{Metode}

Penelitian ini dilaksanakan di Provinsi Bengkulu pada tahun 2017, selama 5 (lima) bulan yaitu pada Bulan Agustus-Desember 2017. Lokasi pelaksanaan kegiatan adalah di seluruh wilayah kabupaten/kota se Provinsi Bengkulu, yaitu Kabupaten Mukomuko, Kabupaten Bengkulu Utara, Kabupaten Bengkulu Tengah, Kabupaten Seluma, Kabupaten Bengkulu Selatan, Kabupaten Kaur, Kabupaten Kepahiang, Kabupaten Rejang Lebong, Kabupaten Lebong dan Kota Bengkulu.

Adapun lokasi kegiatan survei penilaian terhadap Daya Tarik Wisata (DTW) ditetapkan atas usulan masing-masing pemerintah kabupaten/kota berdasarkan DTW unggulan, seperti yang disajikan pada Tabel 3.1 berikut ini. 
Tabel 1. Obyek Daya Tarik Wisata (DTW) yang menjadi sebagai lokasi survei pada setiap kabupaten/kota di Provinsi Bengkulu (Tahun 2017)

\begin{tabular}{|c|c|c|}
\hline No. & Kabupaten/Kota & DTW Yang Di Survei \\
\hline \multirow[t]{3}{*}{1} & Kabupaten Kaur & Danau Kembar, dan \\
\hline & & Pantai Laguna \\
\hline & & Pantai Way Hawang \\
\hline \multirow[t]{3}{*}{2} & Kabupaten Bengkulu Selatan & Pantai Pasar Bawah Manna \\
\hline & & Arung Jeram \\
\hline & & Air Terjun Geluguran \\
\hline \multirow[t]{3}{*}{3} & Kabupaten Seluma & Air Terjuan Bekinyau \\
\hline & & Pantai Alas Maras \\
\hline & & Kawasan Lubuk Resam \\
\hline \multirow[t]{5}{*}{4} & Kota Bengkulu & Pantai Panjang \\
\hline & & Danau Dendam Tak Sudah \\
\hline & & Rumah Bung Karno \\
\hline & & Benteng Marlborough \\
\hline & & Pulau Tikus \\
\hline \multirow[t]{4}{*}{5} & Kabupaten Bengkulu Tengah & Pantai Sungai Suci \\
\hline & & Danau Gedang \\
\hline & & Habitat Bunga Raflesia \\
\hline & & Air Terjun Datar Lebar \\
\hline \multirow[t]{3}{*}{6} & Kabupaten Kepahiang & Kawasan Kabawetan \\
\hline & & Air Terjun Curug Embun \\
\hline & & Danau Suro \\
\hline \multirow[t]{3}{*}{7} & Kabupaten Rejang Lebong & Wisata Air Panas Suban \\
\hline & & Danau Mas Bestari \\
\hline & & Bukit Kaba \\
\hline \multirow[t]{3}{*}{8} & Kabupaten Lebong & Danau Tes \\
\hline & & Arung Jeram \\
\hline & & Kawasan Air Putih \\
\hline \multirow[t]{3}{*}{9} & Kabupaten Bengkulu Utara & Air Terjun Palak Siring \\
\hline & & Air terjun Curug Sembilan \\
\hline & & Pulau Enggano \\
\hline \multirow[t]{3}{*}{10} & Kabupaten Mukomuko & Padang Penaek \\
\hline & & Danau Nibung \\
\hline & & Danau Lebar \\
\hline
\end{tabular}


Pada Tabel 1 diatas dapat diketahui, bahwa ada 32 DTW yang disurvei di Provinsi Bengkulu, yaitu masing-masing adalah Kabupaten Kaur (3 DTW), Kabupaten Bengkulu Selatan (3 DTW), Kabupaten Seluma (3 DTW), Kota Bengkulu (4 DTW), Kabupaten Bengkulu Tengah (4 DTW), Kabupaten Kepahiang (3 DTW), Kabupaten Rejang Lebong (3 DTW), Kabupaten Lebong (3 DTW), Kabupaten Bengkulu Utara (3 DTW) dan Kabupaten Mukomuko (3 DTW). Keseluruhan DTW yang dikunjungi di setiap kabupaten/kota di Provinsi Bengkulu tersebut terdiri dari wisata alam, wisata bahari dan wisata sejarah.

Penilaian Daya Tarik Wisata dilakukan secara sistematis dan aktual mengenai daya tarik wisata Provinsi Bengkulu. Pengolahan data dilanjutkan dengan kegiatan analisis data. Analisis data diperlukan untuk melakukan penafsiran terhadap seluruh data primer yang sudah dikumpulkan sehingga diperoleh suatu kesimpulan yang dibutuhkan untuk menjawab tujuan dari pelaksanaan kegiatan ini. Komponen yang dinilai sesuai dengan tabel 2 yaitu: (1) Daya Tarik (2) Amenitas/Fasilitas (3) Aksesibilitas dan (4) Pengelolaan.

Penilaian untuk setiap kriteria DTW dihitung dengan menggunakan rumus sebagai berikut :

$\mathrm{S}=\mathrm{N} \times \mathrm{B}$, dimana :

S= Skor/nilai suatu kriteria/Nilai Bobot

$\mathrm{N}=$ Jumlah nilai dasar

$\mathrm{B}=$ Bobot nilai

Nilai dasar adalah jumlah nilai per indikator. Setiap indikator memiliki beberapa parameter seperti pada tabel 2, nilai tertinggi per parameter adalah 25 dan nilai terendah per parameter adalah 10. Sedangkan untuk bobot nilai adalah nilai bobot per indikator. Bobot nilai diambil berdasarkan Pedoman Penilaian Daya Tarik Wisata. Kementerian Kebudayaan dan Pariwisata. Berikut tabel bobot indikator penilaian klasifikasi daya tarik. 
Tabel 2. Tabel Bobot Indikator Penilaian DTW di masing-masing kabupaten/kota di Provinsi Bengkulu (Tahun 2017)

\begin{tabular}{|c|c|c|c|}
\hline No. & Indikator & Bobot & Penjelasan \\
\hline 1. & $\begin{array}{l}\text { Atraksi/ } \\
\text { Daya Tarik Wisata }\end{array}$ & 6 & $\begin{array}{l}\text { Atraksi/Daya Tarik Wisata Adalah Unsur } \\
\text { Utama Dalam Produk Pariwisata. Daya } \\
\text { Tarik Wisata Adalah Semua Objek Dan } \\
\text { Atraksi Yang Tersedia Sebagai Daya Tarik } \\
\text { Mengapa Wisatawan Mau Datang } \\
\text { Berkunjung Ke Dtw Tersebut. No } \\
\text { Attraction, No Destination. }\end{array}$ \\
\hline 2. & $\begin{array}{l}\text { Amenitas/ } \\
\text { Fasilitas Wisata }\end{array}$ & 5 & $\begin{array}{l}\text { Unsur Penting Pembentuk Produk } \\
\text { Pariwisata. Fasilitas/Amenitas Wisata } \\
\text { Adalah Penunjang Kegiatan Pariwisata } \\
\text { Atau Semua Bentuk Fasilitas Yang } \\
\text { Memberikan Pelayanan Bagi Wisatawan } \\
\text { Untuk Segala Kebutuhan Selama Tinggal } \\
\text { Atau Berkunjung Pada Suatu Dtw, }\end{array}$ \\
\hline 3. & Aksesibilitas & 5 & $\begin{array}{l}\text { Aksesibilitas Merupakan Salah Satu } \\
\text { Unsur Utama Dalam Produk. } \\
\text { Aksesibilitas Adalah Kemudahan Untuk } \\
\text { Mencapai Daerah Tujuan Wisata Tersebut } \\
\text { Dan Kemudahan Memperoleh Informasi } \\
\text { Dtw. }\end{array}$ \\
\hline 4. & Pengelolaan & 3 & $\begin{array}{l}\text { Pengelolaan Mencakup Keberadaan } \\
\text { Dokumen Pengelolaan Seperti Rencana } \\
\text { Pengembangan Dan Pengelolaan Daya } \\
\text { Tarik Wisata Kawasan, Kemantapan } \\
\text { Organisasi Pengelolaan, Mutu Pelayanan, } \\
\text { Dan Kelengkapan Sarana Pendukung Dan } \\
\text { Perawatan. }\end{array}$ \\
\hline
\end{tabular}

Selanjutnya untuk penentuan klasifikasi Obyek Daya Tarik Wisata (DTW) dilakukan dengan menggunakan Indeks Kelayakan menurut Karsudi, et al. (2010), yaitu sebagai berikut: 
1. Tingkat Kelayakan $>66,6 \%$; potensial/layak dikembangkan, dengan kriteria suatu kawasan wisata yang memiliki potensi, sarana dan prasarana yang tinggi berdasarkan parameter yang telah ditetapkan serta didukung oleh aksesibilitas yang memadai.

2. Tingkat Kelayakan 33,3 \% - 66,6 \%; cukup potensial/cukup layak dikembang, dengan kriteria suatu kawasan wisata yang memiliki potensi, sarana dan prasarana yang sedang, berdasarkan parameter yang telah ditetapkan serta didukung oleh aksesibilitas yang memadai.

3. Tingkat Kelayakan $<33,3 \%$; tidak potensial/belum layak dikembangkan, kriteria suatu kawasan wisata yang memiliki potensi, sarana dan prasarana yang rendah, berdasarkan parameter yang telah ditetapkan serta didukung oleh aksesibilitas yang memadai.

\section{Hasil dan Pembahasan}

Berdasarkan indikator penilaian daya tarik wisata dan pengamatan langsung dilapangan, maka didapatlah hasil penilaian berupa diagram di setiap daya tarik wisata yang diunggulkan setiap kabupaten. Seperti yang sudah dijelaskan di Bab II bahwa indikator penilaian daya tarik wisata terdiri atas Atraksi, Amenitas/Fasilitas, Aksesibilitas, dan Pengelolaan setiap DTW yang masing-masing indikator penilaian memiliki bobot nilai masing-masing sesuai dengan tingkat kebutuhan daya tarik wisata. Berikut hasil penilaian Daya Tarik Wisata Provinsi Bengkulu.

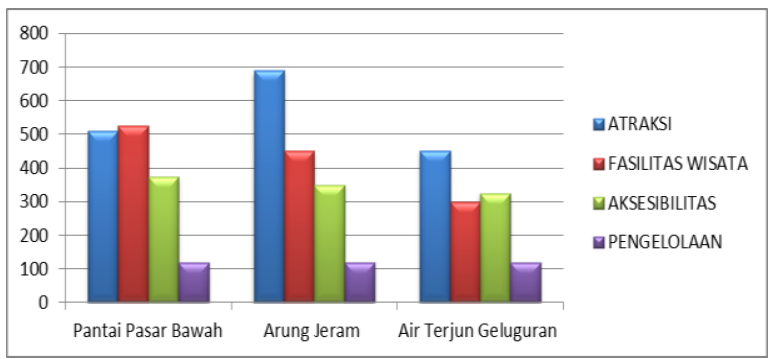

Diagram 1 Hasil Analisa DTW di Kabupaten Bengkulu Selatan

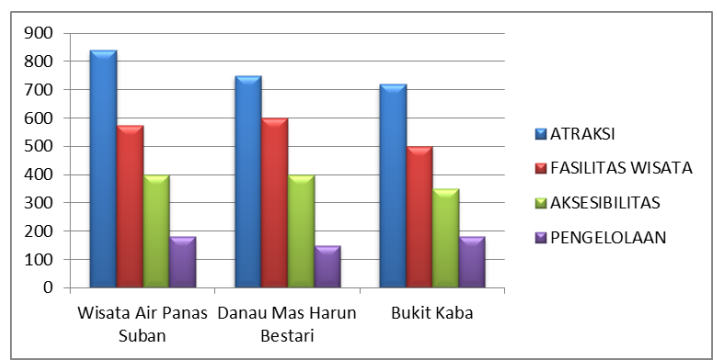

Diagram 2 Hasil Analisa DTW di Kabupaten Rejang Lebong, 2017 


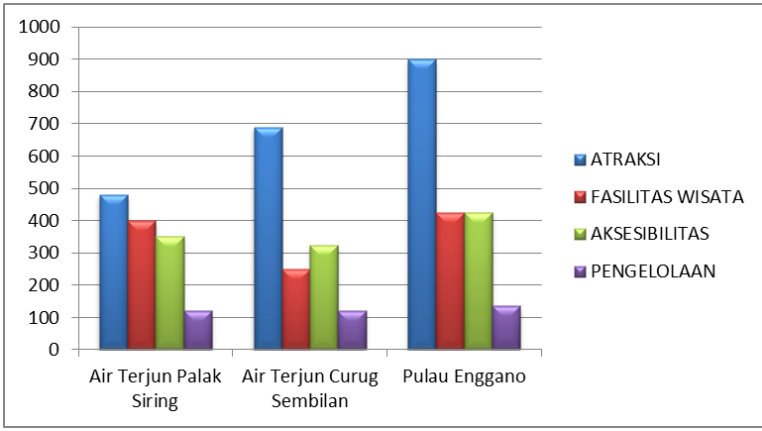

Diagram 3. Hasil Analisa DTW di Kabupaten Bengkulu Utara, 2017

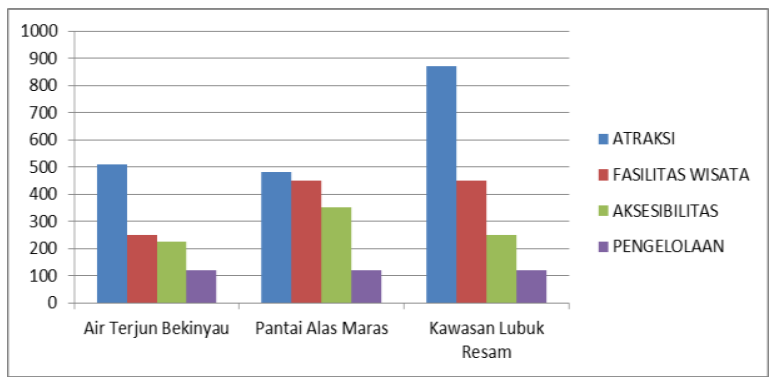

Diagram 5. Hasil Analisa DTW di Kabupaten Seluma, 2017

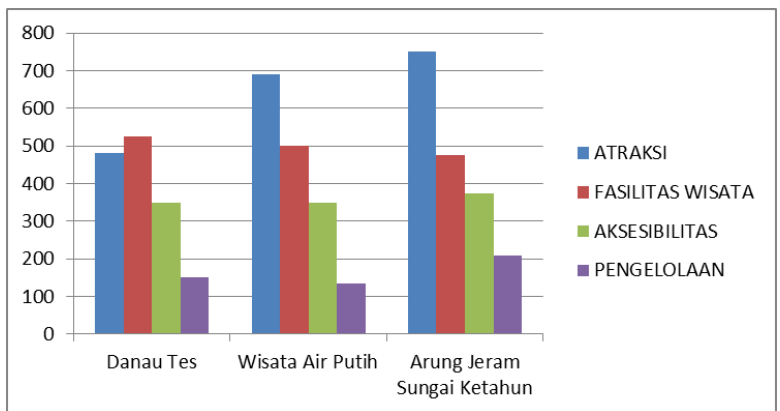

Diagram 7. Hasil Analisa DTW di Kabupaten Lebong, 2017

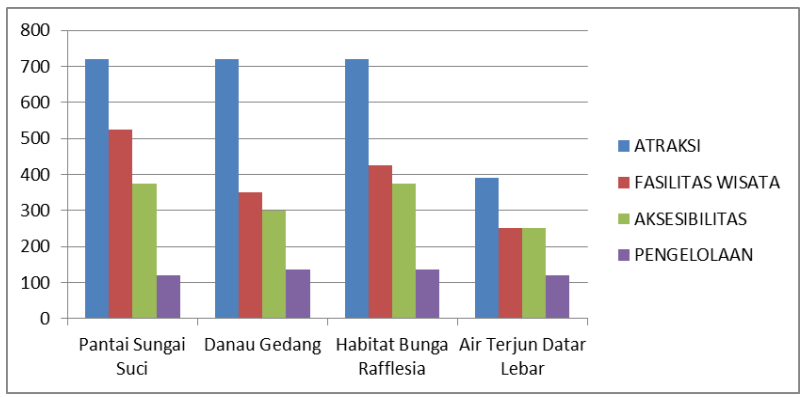

Diagram 9. Hasil Analisa DTW di Kabupaten Bengkulu Tengah, 2017

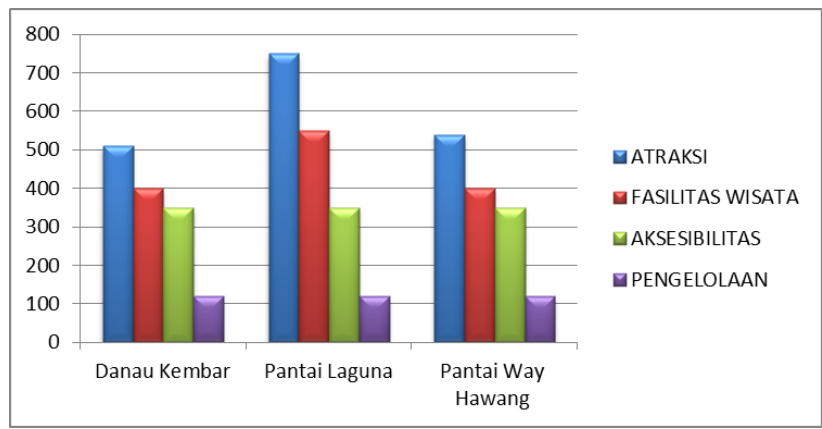

Diagram 4. Hasil Analisa DTW di Kabupaten Kaur, 2017

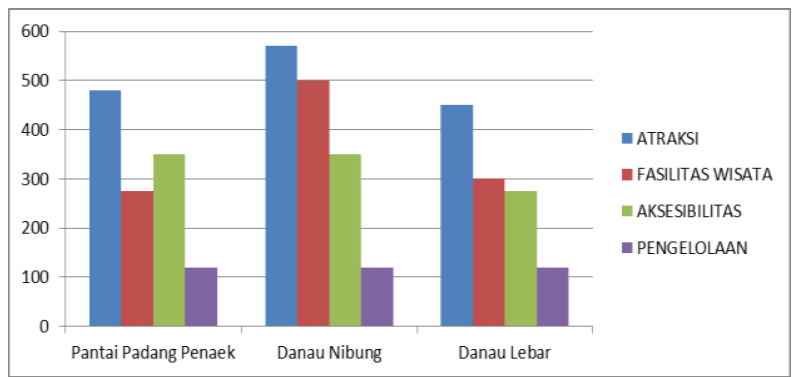

Diagram 6. Hasil Analisa DTW di Kabupaten Muko-Muko, 2017

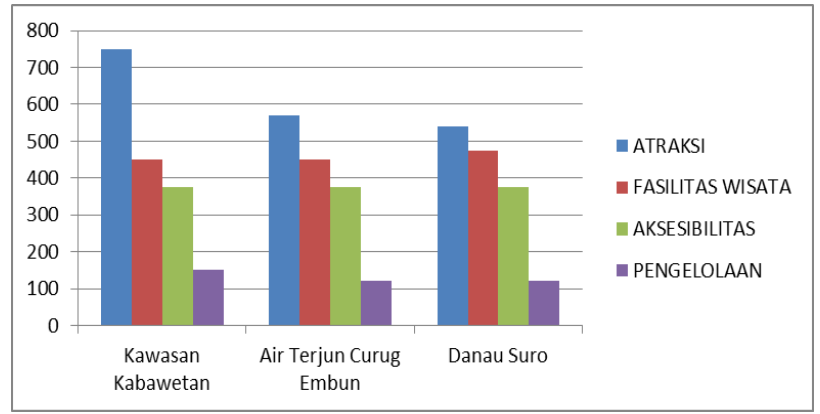

Diagram 8. Hasil Analisa DTW di Kabupaten Kepahiang, 2017

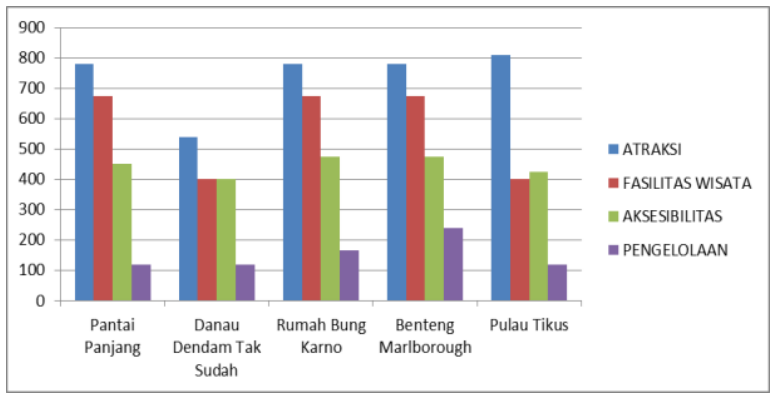

Diagram 10. Hasil Analisa DTW di Kota Bengkulu, 2017 
Berdasarkan pengumpulan data yang dilakukan dengan metode observasi lapangan, wawancara, penilaian/ assesment, dan dokumentasi daya tarik wisata, dan melakukan analisis data dengan guidline, maka didapatlah klasifikasi daya tarik wisata untuk diunggulkan di setiap kabupaten yang terdiri atas tiga (3) klasifikasi, yaitu klasifikasi potensi/layak dikembangkan, cukup potensi/layak dikembangkan, dan klasifikasi tidak potensi/ belum layak dikembangkan. Berikut diagram hasil rekapitulasi penilaian Daya Tarik Wisata Provinsi Bengkulu.

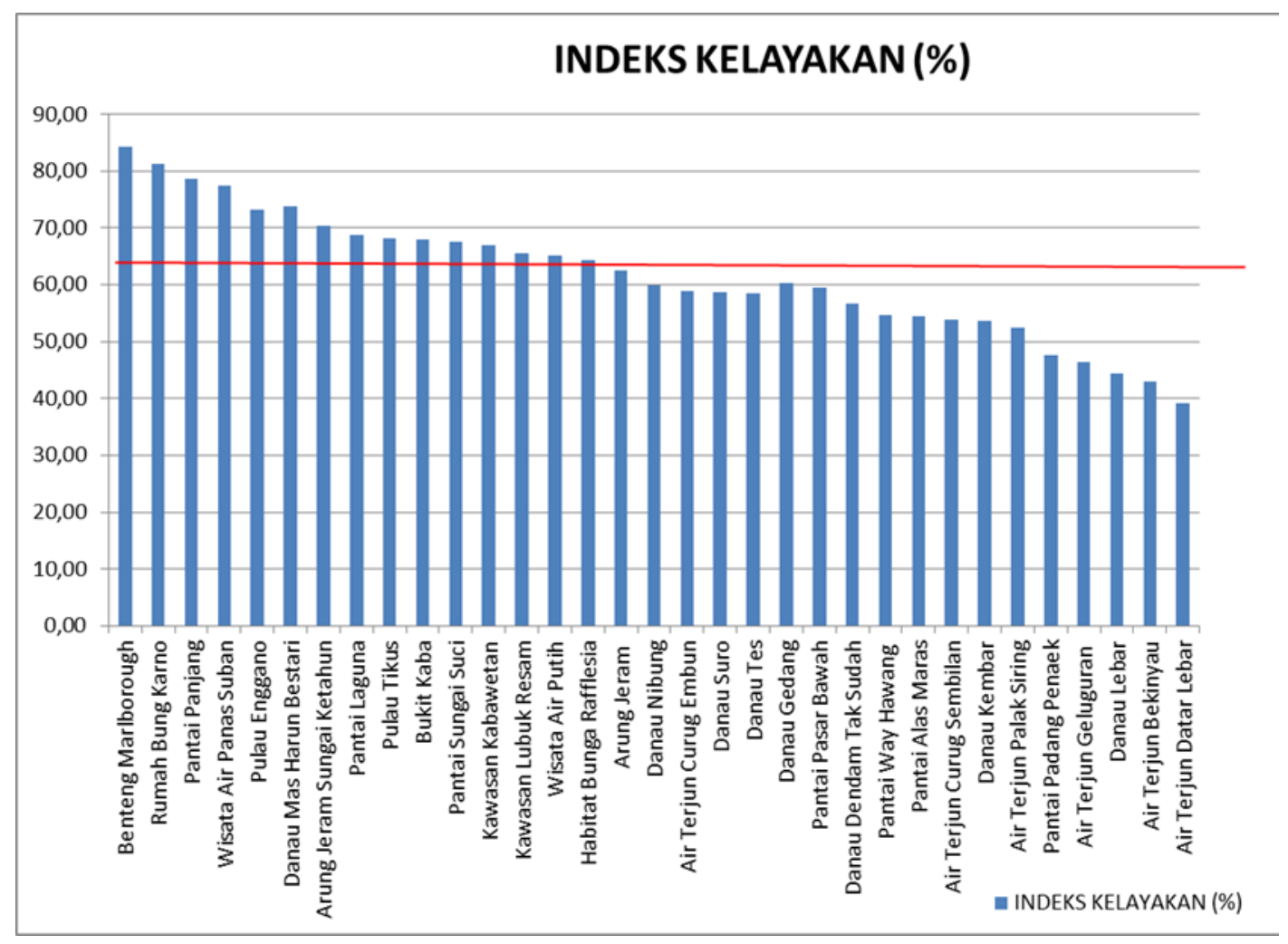

Diagram 11. Hasil rekapitulasi penilaian Daya Tarik Wisata Provinsi Bengkulu Sumber: Analisa 2017

Berdasarkan diagram 11 dari 33 daya tarik wisata terdapat 12 daya tarik wisata yang termasuk dalam klasifikasi potensi/layak dikembangkan dan 21 daya tarik wisata yang termasuk dala klasifikasi cukup potensi/layak dikembangkan. 12 daya tarik wisata yang termasuk kategori potensi/layak dikembangkan adalah Benteng Marlborough, Kota Bengkulu (84,27\%), Rumah Bung Karno, Kota Bengkulu (81,36\%), Pantai Panjang Kota Bengkulu (78,64\%), Wisata Air Panas Suban, Rejang Lebong (77,48\%), Pulau Enggano, Bengkulu Utara (73,20\%), Danau Mas Harun 
Bestari, Rejang Lebong (73,79\%), Arung Jeram Sungai Ketahun, Lebong (70,29\%), Pantai Laguna Kaur (68,74\%), Pulau Tikus, Kota Bengkulu (68,16\%), Bukit Kaba, Rejang Lebong (67,96\%), Pantai Sungai Suci, Bengkulu Tengah (67,57\%), dan Kawasan Kabawetan, Kepahiang (66,99\%). 12 daya tarik wisata ini memiliki indeks kelayakan $>66,6 \%$ seperti terlihat didiagram 4.11 . Hasil klasifikasi daya tarik wisata ini diharapkan dapat menjadi acuan dalam pengembangan daya tarik wisata Provinsi Bengkulu.

\section{Simpulan dan Saran}

\section{Simpulan}

Provinsi Bengkulu memiliki potensi pariwisata yang cukup potensial, baik daya tarik wisata alam, wisata buatan, mapuan wisata budaya/sejarah yang tersebar di 10 kabupaten/kota Provinsi Bengkulu. Namun, secara umum potensi DTW ini masih belum diimbangkan oleh kondisi aksesibilitas maupun fasilitas/ amenitas yang memadai. Sehingga tidak dapat mendukung pengembangan kepariwisataan secara optimal. Pengelolaan hampir seluruh daya tarik wisata di 10 kabupaten/kota di Provinsi Bengkulu secara umum masih lemah, baik dari segi kepengurusannya maupun dalam tatanan perencanaan pengembangan destinasi wisata.

Dari 33 daya tarik wisata yang diteliti se-Provinsi Bengkulu, terdapat 12 daya tarik wisata yang termasuk dalam klasifikasi potensi/layak dikembangkan dan 21 daya tarik wisata yang termasuk dalam klasifikasi cukup potensi/layak dikembangkan. 12 daya tarik wisata yang termasuk kategori potensi/layak dikembanggkan adalah Benteng Marlborough, Kota Bengkulu (84,27\%), Rumah Bung Karno, Kota Bengkulu (81,36\%), Pantai Panjang Kota Bengkulu (78,64\%), Wisata Air Panas Suban, Rejang Lebong (77,48\%), Pulau Enggano, Bengkulu Utara (73,20\%), Danau Mas Harun Bestari, Rejang Lebong (73,79\%), Arung Jeram Sungai Ketahun, Lebong (70,29\%), Pantai Laguna Kaur (68,74\%), Pulau Tikus, Kota Bengkulu (68,16\%), Bukit Kaba, Rejang Lebong (67,96\%), Pantai Sungai Suci, 
Bengkulu Tengah (67,57\%), dan Kawasan Kabawetan, Kepahiang (66,99\%). 12 daya tarik wisata ini memiliki indeks kelayakan $>66,6 \%$.

\section{Saran}

Berdasarkan penilaian menurut indikator penilaian daya tarik wisata terdiri atas (1) Atraksi, (2) Amenitas/Fasilitas, (3) Aksesibilitas, dan (4) Pengelolaan, maka dapat diketahui kekurangan dan kelebihan masing-masing DTW di setiap kabupaten/kota Provinsi Bengkulu. Sehingga hasil klasifikasi daya tarik wisata di Provinsi Bengkulu diharapkan dapat menjadi acuan dalam perencanaan dan pengembangan daya tarik wisata Provinsi Bengkulu untuk kedepannya sesuai dengan baik dari Atraksi, Amenitas/Fasilitas, Aksesibilitas, dan Pengelolaan dalam mewujudkan suksesnya Event Besar “Visit 2020 Wonderful Bengkulu”.

\section{Daftar Pustaka}

Basiya, R., Rozak, H. A., Kualitas Daya tarik Wisata, Kepuasan Dan Niat Kunjungan Kembali Wisatawan Mancanegara Di Jawa Tengah. Jurnal Dinamika Kepariwisataan, 2012, Vol. XI No.2, hal 1-12.

Dinas Budaya dan Pariwisata. Pedoman Penilaian Daya Tarik Wisata

Direktorat Jenderal Pengembangan Destinasi Pariwisata. Pola Pengembangan Destinasi Pariwisata Nasional. Direktorat Jenderal Pengembangan Destinasi Pariwisata, Departemen Kebudayaan Dan Paraiwisata. Jakarta. 2009.

Karsudi, R. Soekmadi,H., Kartodiharjo., Strategi Pengembangan Ekowisata di Kabupaten Kepulauan Yapen Provinsi Papua. JMHT, 2010, Vol.XVI, No. 3, Hal: 148-154.

Pendit, N., Ilmu Pariwisata. Akademi Pariwisata Trisakti, Jakarta, 1999.

Suwantoro, G., Dasar-Dasar Pariwisata. Penerbit ANDI Offset, Yogyakarta, 2004.

Yoeti, O.A., Perencanaan dan Pengembangan Pariwisata. PT. Karya Unipress, Jakarta, 1997.

Yoeti, O.A., Perencanaan dan Pengembangan Pariwisata. PT. Pradnya Paramita, Jakarta, 2008. 
Peraturan Pemerintah Republik Indonesia Nomor 50 Tahun 2011 Tentang Rencana Induk Pengembangan Kepariwisataan Nasional Tahun 2010-2025.

Undang-Undang Republik Indonesia Nomor 10 Tahun 2009 Tentang Kepariwisataan

https://finance.detik.com/berita-ekonomi-bisnis/d-3687715/tiga-tahun-jokowi-jkpariwisata-sumbang-devisa-terbesar-kedua, 17/03/2018

\section{Profil Penulis}

Dwi Oktavallyan Saputri, S.T., M.Sc. adalah dosen Fakultas Teknik Prodi Arsitektur, Universitas Bengkulu, Bengkulu. Dwi menyelesaikan program sarjana di Fakultas Teknik Jurusan Arsitektur Universitas Diponegoro tahun 2013, program magister di Fakultas Teknik Jurusan Arsitektur Konsentrasi Arsitektur dan Perencanaan Pariwisata Universitas Gadjah Mada tahun 2016. Minat penelitian dwi adalah arsitektur dan pariwisata.

Ir. Zamdial Ta'alidin, M.Si. adalah dosen Program Studi Ilmu Kelautan Fakultas Pertanian Universitas Bengkulu. Zamdial menyelesaikan program sarjana dan program magister di IPB tahun 2000. Minat penelitian zamdial adalah bidang kelautan dan pariwisata.

Atik Prihatiningrum, S.T., M.Sc. adalah dosen Fakultas Teknik Prodi Arsitektur, Universitas Bengkulu, Bengkulu. Atik menyelesaikan program sarjana di Fakultas Teknik Jurusan Arsitektur Universitas Sebelas Maret tahun 2014, program magister di Fakultas Teknik Jurusan Arsitektur Konsentrasi Kawasan Binaan Universitas Gadjah Mada tahun 2016. Minat penelitian atik adalah arsitektur dan kawasan binaan. 